\title{
Suomalaisten
}

\section{koulutusuudistusten ja talouden yhteyksistä}

\author{
Hannele Salminen
}

Koulutusta pidetään kansantalouden kehitysveturina. Koulutusuudistuksille ja koulutukselle on asetettu tavoitteeksi turvata yhteiskunnan suotuisa taloudellinen kehitys. Suomessa on tehty mittavia koulutusreformeja vakaan taloudellisen kasvun ja koulutusoptimismin vallitessa.

Yhtäältä koulutuksen kehittämistä ja koulutusreformeja on pidetty edellytyksenä yhteiskunnan taloudellisen vakauden jatkumiselle ja kasvulle, ja toisaalta vakaaksi tai kasvavaksi uskottu taloudellinen tila näyttää olevan reformien edellytys. Koska uudistukset yleensä vaativat lisäresurssointeja, ne ajoittuvat talouden kasvuvaiheisiin. Lehtisalo ja Raivola $(1992,257)$ toteavat osuvasti koulutus ja koulutuspolitiikan aina taloudellisina laskukausina poteneen hengenahdistusta. Tapausesimerkkeinä mittavista koulutusreformeista on tässä yhteydessä käytetty lähinnä keskiasteen tutkinnonuudistusta, nuorisoasteen koulutuskokeilua ja sen kanssa samanaikaista ammattikorkeakoulujärjestelmän luomista maahamme ammattikorkeakoulukokeilun kautta. 1980-luvun lopulla aloitetut uudistukset toteutettiin lamasta ja leikkauksista huolimatta.

Tässä artikkelissa ei siis käsitellä koulutuksen kustannuksia. Ne vaihtelevat paitsi maittain, myös suuresti kussakin maassa jopa saman koulutusmuodon sisällä (ks. esim. Coombs \& Hallak 1987; Bray, M. \& Lillis, K. 1988). Puhtaita koulutuksen vaikutuksia talouteen tai talouden vaikutuksia koulutukseen ei myöskään voi selittää yksiviivaisesti. Tällaiseen tarkasteluun tulee sisällyttää yhteiskunnan sosiaaliset suhteet sekä talouden ja politiikan yleiset yhteydet. Vaikutuksia on vaikea myöskään mitata empiirisesti, koska koulutus on osa lukemattomien muiden instituutioiden toimintaa yhteisöissä. Häyrynen (1992) huomauttaa, että taloudellinen kasvu on kokonaisilmiö: Kun järjestelmä kaiken aikaa laajenee, useimmat indikaattorit ovat positiivisessa suhteessa kasvun osoittajiin. Siksi tiettyjä yhteyksiä, kuten koulutuksen kasvu - tuottavuuden kasvu, ei tulisikaan tarkastella erillisinä 'kausaalisuhteina'. Muun muassa Gordon (1986) on esittänyt kritiikkiä taloustieteilijöiden kuten Bacon'n ja Eltis'n mekanistista tarkastelutapaa kohtaan. Gordonin mukaan koulutusreformin rajoja tarkas- 
tellaan siinä kapitalististen ja patriarkaalisten ehtojen vallitessa selittämällä 1960 -luvun lopun ja 1970 -luvun alun taloudellisia ideologioita ja tapahtumia.

Koulutusreformeilla tarkoitetaan tässä yhteydessä uudistuksia, joiden nimenomaisina tarkoituksina on ilmaistu positiiviseen muutokseen, koulutuksen sisällön, järjestelmän tai laadun kehittämiseen tähtääviä tavoitteita. Koulutukselle on asetettu myös puhtaasti kulttuurinen sivistystehtävä. Suomessa on voimakkaasti korostunut koulutuksen kulttuuripääoman luonne ja yksilöiden ja perheiden koulutukseen suuntaamat toiveet sosiaalisen nousun välineenä (ks. esim Ahola 1995; Elovainio 1974; Isoaho, Kivinen \& Rinne 1990; Kivinen, Rinne \& Ahola 1989).

\section{KOULUTUS TALOUDELLISEN KASVUN EDELLYTYKSENÄ ?}

Laajoja koulutusuudistuksia on eri aikoina perusteltu erityyppisillä yhteiskunnallisilla tavoitteilla, kuten kansainvälisyys, ammattitaitovaatimukset, demokratia ja tasa-arvo, kansainvälinen talous, julkinen etu ja yksilön etu. Suomalaisiin koulutusta koskeviin mietintöihin alkoi 1900luvun alussa tulla taloudellisia näkökohtia painottavia ilmauksia (Hovi, Kivinen ja Rinne 1989). Lampisen (1998, 28-29) mukaan suomalaista koulutuspolitiikkaa ovat yhteiskunnallisista tavoitteista ohjanneet vahvimmin seuraavat kolme aatetta:

1 kansallisuusaate,

1 taloudellisen kasvun ideologia ja

1 yhteiskunnallisen tasa-arvon tavoittelu.

Lampinen toteaa näiden siivittäneen suurisuuntaisia reformeja. Hän huomauttaa (1998, 63), ettei koulutusta ennen 19. vuosisataa pidetty yhteiskunnallisen muutoksen tekijänä huolimatta koulutuksen ilmeisistä taloudellisista vaikutuksista.

Ammattikorkeakoulujärjestelmän perusteluina olivat toisaalta yhteiskunnan ja sen ammattitaitovaatimusten muutokset, toisaalta koulutusjärjestelmän rakenteelliset epäkohdat, joita uudistuksella haluttiin korjata (ks. Opetusministeriö

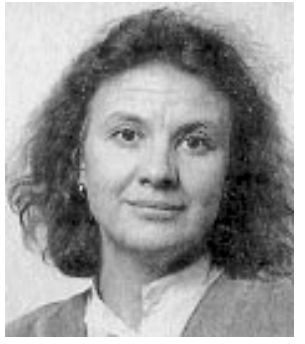

Hannele Salminen

1989; Valtioneuvoston ... 1990; Lampinen - Savola 1995; Salminen 1997; Salminen 1998). Yhteiskunnan vaatimuksiin lukeutui myös talouden turvaaminen koulutuksen tasoa kohottamalla.

OECD:n raportit ovat aina korostaneet koulutuksen merkitystä taloudessa (ks. esimerkiksi Kogan 1979). Niiden lähtökohtana on vaikutusketju, jossa koulutus luo edellytykset talouden kehitykselle, eikä päinvastoin. Koulutuksen ja talouden välinen suhde on kuitenkin varsin monimutkainen ja riippuu useammasta yhteystekijästä. Tätä kompleksisuutta kuvatessaan Peston (1981) luettelee esimerkkeinä talouden vaikutuksesta koulutukseen työvoiman ja resurssien jaon, kilpailun kyvykkäästä työvoimasta sekä tutkimus- ja kehittämistyön. Taloudelliset tekijät vaikuttavat myös siihen, mitä tuotteita kouluilta ja oppilaitoksilta edellytetään ja ne vaikuttavat lisäksi opiskelijoiden opiskeluasenteisiin. Voidaan myös kysyä, nostaako koulutus yksittäisen ihmisen tai koko työvoiman tuottavuutta, ja jos nostaa, miten se tapahtuu, ja mitä muita vaikutuksia sillä on. Kytkennät eivät ole välttämättä suoraviivaisia.

$\mathrm{E}$ tenkin toisen maailmansodan jälkeen koulutusta on käytetty taloudellisten ja sosiaalisten tavoitteiden saavuttamisen välineenä. Tämä näkyy myös suomalaisessa koulutuspoliittisessa tavoitteenasettelussa (ks. Hovi, Kivinen ja Rinne 1989). Yhteiskunnan taloudellisen tilan kohentaminen koulutuksen avulla on esillä esimerkiksi koulu-tuksen tavoiteohjelmatoimikunnan mietinnössä vuodelta 1978 (Koulutuksen....1978). Samoin taloudellisen kasvun tavoite on havaittavissa ammattikorkeakoulu-uudis- 
tuksen yleisissä perusteluissa (ks. Valtioneuvoston koulutuspoliittinen selonteko Eduskunnalle 1990).

$\mathrm{M}$ arkkinatalousmaissa noususuhdanteissa ko rostuu koulutukseen osallistuminen, ts. tasa-arvotavoite, ja laskusuhdanteessa taloudelliset tavoitteet kuten tehokkuus ja tuloksellisuus. Suomen talouden ollessa pitkälti riippuvainen ja tasapainotettu Neuvostoliiton kaupan mukaan tämä piirre ei tullut meillä selvästi esiin. Koko painollaan se oikeastaan näkyy vasta nyt. Silti tämä logiikka on havaittavissa myös aiemmissa koulutusuudistuksille otollisissa 'suvantovaiheissa'. Suomen rakennemuutoksen pitkäaikaista jatkumista voidaan pitää keskeisenä tekijänä taloudellisten tavoitteiden toissijaisuudelle: koulutuspolitiikkaa on pidetty maassamme moneen muuhun maahan verrattuna tärkeänä. Koulutetut ovat myös sijoittuneet työhön laajeneville yhteiskunnan sektoreille.

Markkinaperustaisessa tiedonjärjestyksessä tiede nähdään pelkästään markkinavoimien veturina (Suoranta \& Ylä-Kotola 1999). Tiedolla katsotaan olevan kaiken kaikkiaan merkittävä rooli taloudellisessa kasvussa, koska tieto on eräs perusedellytys innovaatioille, jotka saavat aikaan tehokkaampia tapoja hyödyntää yhteiskunnan henkisiä ja materiaalisia voimavaroja. Koulutus on siis tällöin nähty olennaisena tuotantotekijänä.

Castells (1994) pitää inhimillistä pääomaa strategisena sijoituksena, mutta toteaa samalla, että konkreetit tätä osoittavat politiikan toimet ovat kompleksisempia ja vähemmässä määrin hyväksyttyjä kuin ensi näkemältä vaikuttaisi. Hän pitää korkeakouluja kehityksen perustyökaluina, mutta huomauttaa, että ne ovat sitä aivan eri mielessä kuin mitä humanistinen suunta on esittänyt korostaessaan lukutaitoa ja kulttuurisia tarpeita. Castells (emt) vertaa tiedettä ja teknologisia järjestelmiä nykytaloudessa teollistumisen ajan tehtaisiin: jos tieto on nykyisen talouden sähkövirtaa, korkeakoulut ovat voimalaitoksia, joiden toimintaan uuden kehitysprosessin täytyy pohjautua.

Suomalaisessa koulutuspoliittisessa päätöksenteos- sa on viime vuosina kannettu erityisesti huolta tietoteollisuuden tarpeista 1), koska sillä alueella on tuoreiden asiantuntija-arvioiden mukaan katsottu olevan maallamme huikeat viennin kasvun mahdollisuudet, jos niin yliopisto- kuin ammattikorkeakoulusektorikin tuottavat riittävästi osaavia alan ammattilaisia työelämään. (Ks. esim. Nukari, J. \& Forsell, M. 1999.) Tietoteollisuuden alojen nähdään kasvavan ja tämän osaamisalueen sisältyvän myös lähes kaikkiin muihin "perinteisiin" aloihin, joten kyse ei ole vain yhden alan kasvun turvaamisesta. Tässä katsannossa siis koulutus - laadullisesti riittävän korkeatasoinen ja määrällisesti tietoteollisuuden kasvaviin tarpeisiin riittävä - on nähty välttämättömänä edellytyksenä kansantalouden myönteiselle kehitykselle. Merkille pantavaa on, että tietoteollisuuden koulutuksen lisäys on tehty vuosina, jolloin opetustoimen kokonaisosuus valtion budjetissa ei ole lainkaan kasvanut.

Hernesniemi ym. (1995) toteavat, että tieto on ainoa tuotannontekijä, mikä voi kasvaa rajatta; juuri tämä tekee heidän mukaansa mahdolliseksi jatkuvan taloudellisen kasvun. Se selittää heidän mukaansa myös maiden välisiä kasvu- ja tuottavuuseroja: hyvän koulutusjärjestelmän luoneet ja osaamispääomaa kartuttaneet maat näyttävät kasvaneen muita nopeammin. Tässä myös instituutiot ja taloudelliset kannustimet tulevat kuvaan, sillä koulutuksen lisääminen ei johda automaattisesti talouskasvun nopeutumiseen, elleivät markkinat kohdenna työvoimaa koulutusta vastaaviin tehtäviin ja kasvua tukeville aloille. Kasvun kannalta riittävä työvoiman ammatillinen, toimialoittainen ja alueellinen liikkuvuus toteutuu vain, mikäli uusista tehtävistä ja lisäkoulutuksesta saadaan riittävä taloudellinen hyöty. (Hernesniemi et al, emt.)

$\mathrm{M}$ aailmanpankin asiantuntijat ovat korostaneet koulutuksen yhteyttä talouteen. Yli vuosikymmenen ajan Maailmanpankki on julkaissut lukuisia korkea-asteen koulutusta käsitteleviä tutkimuksia, joissa on tutkittu mm. koulutusinvestointeja ja resurssien käyttöä. Vuonna 1995 ilmestyi sarja "Documents for discussion of the World Bank", jossa esitettiin korkea-asteen koulutuksen relevantti yhteys talouteen ja yhteis- 
kunnalliseen kehitykseen. Tunnermannin (1996) mukaan tämä johtui siitä, että raportti keskittyi niihin taitoihin, joita yksilöt tarvitsevat hoitaessaan vastuullisia tehtäviä hallinnossa, liike-elämässä ja professioissa. Raportissa tarkastellaan uuden tiedon omaksumista, siirtymistä ja välittymistä yhteiskunnassa tarjolla olevien hallintopalvelujen ja konsultoinnin kautta.

Lappalainen (1991) huomauttaa, että toisen maailmansodan jälkeen monissa maissa tehtyjä koulutusratkaisuja on edeltänyt huolestunut julkinen keskustelu, jota on sävyttänyt pelko jäämisestä jälkeen muista maista. Esimerkiksi Englannin koulutuslaki vuoden 1944 pohjautui pitkälle taloudellisen hyvinvoinnin vakiinnuttamiseen. Lindsay (1990) mainitsee, että vaikka asiaa ei aina ilmaistu, koulutuspoliitikkojen keskuudessa syntyi kasvava konsensus siitä, että eri tyyppisillä koulutuksilla voitiin saavuttaa nämä ja muut yhteiskunnalliset tavoitteet. Tällaisen koulutuskilpailun taustalla on ollut ajatus hyvinvoinnin lisäämisestä koulutuksen avulla. Sama ajattelu on havaittavissa nykyisen suomalaisen tietoteollisuuden koulutuksen lisätoimenpideohjelman perusteluissa.

\section{TALOUDEN KASVU KOULUTUSUUDISTUSTEN EDELLYTYKSENÄ}

$V_{\text {hit }}^{\text {at }}$ altiontalouden merkityksestä koulutuksen kehitykselle kertoo Lappalaisen (1991) mukaan se, että suuret koulutusreformit on aina tehty pitkän rauhallisen kehityksen kausina. Asian voi tulkita myös niin, että sotien ja levottomien aikojen patoamat muutostarpeet purkautuvat parempien aikojen tullessa. (Lappalainen emt.) Suomalaisen yhteiskunnan eräänä merkittävänä koulutuspoliittisena linjauksena on pyritty väestön tasa-arvoon turvaamalla maksuton koulutus lapsille ja nuorille. Tätä tavoitetta kohti on tultu asteittain: ensin toteutui kaikille lapsille tarkoitettu kansakoulu vähitellen 1860 -luvulta lähtien; 1921 säädettiin oppivelvollisuuslaki, jonka mukaan kaikkien 7-15 -vuotiaiden oli hankittava kansakoulun oppimäärää vastaavat tiedot.
Vuoden 1957 kansakoululaki sisälsi kansakoulun jälkeisen kansalaiskoulun, joka vapaaehtoisen kolmannen vuosiluokan kanssa tarkoitti parhaimmillaan yhdeksän vuosiluokan kansanopetusta (Numminen 1977). Kaksi viime mainittua uudistusta tehtiin siis ensimmäisen ja toisen maailmansodan jälkeiseen jälleenrakentamisen ja taloudellisen optimismin vuosina.

$\mathrm{T}$ aloudellisen kasvun ideologia oli asetettu tavoitteeksi sotien jälkeisen jälleenrakennuskauden päätyttyä. Pekka Kuusen (1962) sosiaalipoliittinen ohjelma vuonna 1962 nosti taloudellisen kasvun maamme poliittiseksi perustavoitteeksi. Taloudellisen kasvun jatkumiseen uskottiin ja koulutuspoliittiset suunnitelmat rakennettiin sen varaan aina vuoden 1973 energiakriisin asti. (Sarjala 1981, 70-71; Lampinen \& Soininvaara 1980, 141). Kasvun aikana, 1960- ja 1970 -lukujen taitteessa käynnistyi mittava suomalaisen koulutusjärjestelmän uudistus, keskiasteen tutkinnonuudistus. Nousukauden jälkeinen vuoden 1975 taantuma oli ankara (Pekkarinen \& Vartiainen 1993, 325). Silti koulutusjärjestelmäuudistus eteni.

Suomen tapaan Ruotsissa on nähtävissä 1950luvulta alkaen 1980-luvulle koulutusjärjestelmän kehittäminen, joka sisälsi lukuisia laajoja koulutusuudistuksia sekä koulutuksen kasvu, joka on yhteydessä yhteiskunnan vakaaseen taloudelliseen ja poliittiseen tilanteeseen ja vähäiseen työttömyyteen. Marklund $(1984,139)$ mainitsee Ruotsin koulutuskehitystä tarkastellessaan erityisen tärkeänä lisätekijänä materiaalisen hyvinvoinnin kasvun. Ruotsin koulutuspolitiikkaa ja koulutussuunnittelua vuosina 1933-1985 koskevassa tutkimuksessaan Murray (1988) viittaa kehitykseen 1700-luvulta lähtien ja mainitsee sieltä saakka koulutusuudistusten eräänä keskeisenä syynä olleen uskon tekniseen ja taloudelliseen kehitykseen sekä ajatuksen, että näitä voidaan edistää koulutuksen avulla. Marklund (1984) toteaa, että Ruotsissa koulutusreformeja on pidetty yleisesti sekä kohoavien standardien välttämättöminä ehtoina että niiden seurauksena yhä laajenevan joukon vaatiessa pidentyvää koulutusta. Tämä on edellyttänyt taloudellisten voimavarojen sitouttamista koulutusuudistuksiin. 


\section{KOULUTUSOPTIMISMI JA TALOUS}

Theodore W. Schultz esitti vuonna 1960 opin 'inhimillisistä resursseista' ja investoimisesta 'inhimilliseen pääomaan'. Se saavutti otollisen maaperän ajan poliittisessa ja yhteiskunnallisessa ilmastossa. Ajattelutapaa markkinoivat muun muassa Maailmanpankki, Kansainvälinen valuuttarahasto ja OECD ja se tavoitti tehokkaasti sekä poliittisten päätöksentekijöiden että suuren yleisön. Koulutuksen tehtäväksi todella tuli taloudellisen kasvun edistäminen. Samalla koulutus kytkettiin kansainväliseen kilpailuun. Antikainen arvelee, että paljolti tämän, ilmeisesti aikamme populaareimman koulutusteorian katveessa koulutusjärjestelmät ovat kehittyneet nykyisiin mittoihinsa ja muotoihinsa. Hän mainitsee tätä 1960-luvulla ja 1970-luvun alussa kiteytynyttä koulutusajattelua sittemmin luonnehditun muun muassa 'ihanan yksinkertaisuuden idylliseksi ajaksi', joka jo seuraavalla vuosikymmenellä koki merkittäviä takaiskuja. (Antikainen 1986)

Vahva koulutusoptimismi säilyi Suomessa 1980 -luvulla, vaikka toisen maailmansodan jälkeinen taloudellisen kasvun ja hyvinvointivaltion kausi olikin pysyvästi taittumassa, kuten Antikainen vuonna 1986 osuvasti ennakoi. Koulutukseen suunnattuja varoja ei Suomessa 1980-luvulla leikattu, toisin kuin monissa muissa länsimaissa. Tämä tapahtui Suomessa vasta 1990-luvun alkuvuosina. Antikainen (1986) huomauttaa, että 1980 -luvun teollistuneessa maailmassa rikkumaton koulutusoptimismimme oli harvinaista, ellei jopa ainutlaatuista. Muissa OECD-maissa 1960 -luvun ja vielä 1970-luvun alun koulutusoptimismi oli vaihtunut epävarmuudeksi. Papadopoulos (1994) toteaa OECD-maita koskien, että seitsemänkymmentäluvun puoliväliin mennessä tuli ilmeiseksi, että edellisen vuosikymmenen, siis 1960-luvun, koulutuseuforia väistyi tulevaisuuden koulutusnäkymiä koskevan huolen edessä. Muutos oli asteittainen, ja kosketti nopeammin koulutuspolitiikan tekijöitä ja suunnittelijoita kuin käytännön opetustyössä toimivia, opettajia, opiskelijoita ja vanhempia. Raivola (1992) sen sijaan esittää näkemyksen, että koulu- tusevankeliumiin uskovien määrä alkoi lisääntyä taas 1980 -luvulla. Hänen tarkastelukulmansa tässä on globaali. Koulutusorganisaatioilta alettiin vaatia vaikuttavuutta, tehokkuutta ja tulosvastuuta. Uusi nousu rajasi koulutuksen tehtävät kuitenkin pääasiassa taloudellisiksi: koulutuksen tuli olla tehokas väline työllisyyden edistämiseen, ammattitaidon kehittämiseen ja maailmanlaajuisesta kilpailusta selviämiseen. Raivolan (emt) mukaan hidastunut taloudellinen kasvu kuitenkin hillitsi koulutusjärjestelmän laajentamista.

Kogan (1979) toteaa 1960-luvulla vallinneen yleisen optimismin koulutuksen roolista hyvän elämän luomisessa ja kukoistavan talouden ja kulttuurin aikaansaamisessa. Myös tässä näkyy talouden ja koulutuksen kytkentä: Kogan pitää talouden kasvua eräänä 1960-luvun koulutusoptimismin syynä. Toinen oli usko rationaaliseen suunnitteluun. Oletettiin, että oli mahdollista eritellä koulutuspolitiikka suhteessa ulkopuolisiin talouden ja sosiaalisten liikkeiden aspekteihin, ja että olisi mahdollista edetä kohti systemaattisia ratkaisuja: vaurautta voitaisiin suunnitella, ja koulutusta voitaisiin suunnitella vaurauden komponenttina, sekä pääomana että kulutushyödykkeenä. Mutta sittemmin epävarmuus lisääntyi. Usko taloudelliseen kasvuun, parannuksiin yhteiskunnassa ja siihen että koulutus voisi vaikuttaa molempiin, väistyi epävarmuuden ja pessimismin tieltä. (Kogan 1979) Myös Raivola (1992) esittää käsityksenään, että into koulutusjärjestelmien kehittämiseen laantui teollistuneissa maissa 1970-luvun loppupuolella, jolloin monet yhteiskunnallisessa tilanteessa ilmenneet seikat saattoivat poliitikot ja koulutussuunnittelijat ymmälle, radikaali koulutussosiologia heitti vettä kiukaalle osoittaessaan järjestelmän toimivan monilta osiltaan epätarkoituksenmukaisesti ja sisältävän monia piilofunktioita. Yleinen pessimismi koulutuksen mahdollisuuksista kasvoi.

\section{Teoria inhimillisestä pä ä o m a s t a}

Vielä 1970-luvun alussa uskottiin, että koulutukseen investoiminen on aina yksilölle taloudellisesti kannattavaa. Kyseisellä vuosikymmenellä 
kehitettiin ns. inhimillisen pääoman teoria, jossa koulutus, tuottavuus ja tulotaso kytkettiin toisiinsa. 1980-luvulla alettiin puhua koulutusinflaatiosta ja liikakoulutuksesta ja epäillä koulutuksen hyötyä investointina. Muihin Pohjoismaihin verrattuna usko koulutuksen merkitykseen sosiaalisen nousun välineenä oli edelleen 1990-luvun alussa nähtävissä mm. suomalaisten suhteellisesti muita maita suurempana osallistumisena yleissivistävään koulutukseen (Elovainio, P. 1992). Aikakauden dokumenttina Kivinen, Rinne ja Ahola $(1989,9)$ kirjoittavat: "Läntisistä sivilisaatioista on laajentunut maailmaan järkkymätön usko sivistyksen kaikkivoipaisuuteen. Luottamus koulutukseen edistämässä yksilöiden hyvää ja kansakunnan parasta on vielä ehtymätön."

Aiempina vuosikymmeninä suomalaisessa teollistamis- ja kasvupolitiikan työvoimapoliittisessa argumentoinnissa korostettiin maan koko työvoimavarannon saamista yhtenäisen suunnittelun ja politiikan kohteeksi (Kalela 1989). Nyt tiedämme, että tietyillä aloilla ei useaan vuoteen tule juurikaan olemaan uutta työvoiman kysyntää. Silti katsotaan mielekkääksi kouluttaa ihmisiä tulevaisuutta silmällä pitäen, eikä radikaaleihin koulutuspaikkojen vähennyksiin kriittisilläkään koulutusaloilla ole ryhdytty. Koulutusoptimismi ei liity pelkästään talouden kehitykseen. Siihen sisältyy monia ulottuvuuksia. Eräs niistä on ihmisen henkisten voimavarojen kasvattaminen, eräs on talouden kytkentä.

\section{KOULUTUSREFORMIEN VOIMAKENTÄT}

$\mathrm{K}_{\mathrm{k}}$ uviossa 1. esitetään Isling'n (1980) mu kaan laadittu reformien analyysimalli. Se voidaan nähdä eräänä teoreettisena viitekehyksenä, jossa koulutuspoliittisia toimia ja reformeja voidaan tarkas-tella. Tässä yhteydessä mallissa pääosin tarkastellaan suomalaista ammattikorkeakoulureformia. Mallin mukaan reformi lähtee liikkeelle ja toteutuu kolmen pääkentän, taloudellisen, ideo-logis-kulttuurillisen ja poliittis-juridisen kentän välisen vuorovaikutuksen seurauksena. Islingin mukaan reformien päävoimana ovat nimenomaan muutokset taloudellisessa kentässä, jotka aiheutuvat tuotannon ja tuotantovälineiden muutoksista. Taloudellinen kenttä sisältää tuotantomenetelmät, -voimat ja tuotantosuhteet. Tuotannontekijöihin kuuluvat luonnonvarat, työ, reaalipääoma ja tieto (Meklin 1997). Taloudellisiin voimiin voidaan katsoa kuuluvan taloudellisen kasvun tai markkinoiden heikkenemisen.

$\mathrm{K}$ un suomalaista keskiasteen tutkinnonuudistusta ja ammattikorkeakoulureformin käynnistymistä tarkastellaan Islingin mallissa, voidaan todeta, että kumpaankin ajankohtaan ajoittuu muutos tuotantorakenteissa. 1960-70 -lukujen vaihteessa ja 1970-luvun alussa suomalainen yhteiskunta kaupungistui nopeasti ja maatalous- ja teollisuuselinkeinot alkoivat vähentyä palveluammattien lisääntyessä ja näissä toimivien määrien kasvaessa. 1980-luvun lopussa oli jälleen havahduttu työelämän ammattirakenteiden muutoksiin, työsuhteiden epävakaistumiseen sekä tuotantomenetelmien muutoksiin, joilla tuolloista reformia myös perusteltiin. Rakennemuutoksen jatkuvuus Suomessa tekee Islingin ajattelun ehkä vielä sopivammaksi Suomessa kuin Ruotsissa, puhumattakaan esimerkiksi Englannista. Myös tietopääoma kasvoi yhteiskunnan eri alueilla eksponentiaalisesti, ja käsitys tiedon luonteesta muuttui.

Vakaaseen talouden jatkumoon uskottiin myös ammattikorkeakoulukokeilun käynnistyessä 1980-luvun lopun korkeasuhdanteen seurauksena. Tosiasiassa kuitenkin em. korkeasuhdanteen jälkeinen lama johti vuosina 1990-93 yhteensä noin 14 prosentin suuruiseen BKT:n laskuun, ja samaan aikaan työttömyys kasvoi ennätyslukemiinsa tällä vuosisadalla, mikä kasvatti julkisia menoja (Loikkanen \& Pekkarinen \& Siimes \& Vartia 1997).

Islingin mukaan muutokset tuotetaan sosiaalisessa rakenteessa, ja siitä seurauksena olevissa uusissa mielenkiinnon kohteissa ja eturistiriidoissa, jotka näkyvät sekä ideologisissa että poliittisissa elämänpiireissä. Yhteiskunnalliset uudistukset, kuten koulutusreformit, tuodaan esille näissä konflikteissa. Nämä puolestaan vaikutta- 
vat kentän voimiin. Samoin ne vaikuttavat eturyhmiin ja etuihin, jotka olivat reformien ja taistelujen taustalla. Ammattikorkeakoulureformin käynnistyessä eturistiriita ilmeni erityisesti suhteessa yliopistosektoriin (ks. Salminen 1997) ja myöhemmin jossain määrin myös ammatillisen toisen asteen koulutukseen resursseista käytävän kilpailun ja koulutuksen statuksen vuoksi.

I slingin mallia voi tulkita siten, että kun taloudellinen voimakenttä $\mathrm{A}$ on talouskasvun ansiosta suosiollinen koulutusreformille, uudistuksia ryhdytään toteuttamaan. Uudistukset kuitenkin edellyttävät taloudellisen voimakentän ohella, että uudistuksen perustelut ja tavoitteet, jotka koulutuksessa pääosin sijoittuvat ideologis-kulttuuriseen B-kenttään, ovat riittävän voi- makkaita saadakseen liikettä aikaan ja toimivat muutosta vauhdittavina tekijöinä. Poliittis-juridinen voimakenttä $C$ on julkisen keskustelun foorumi, jossa erilaiset koulutuspoliittiset ja puoluepoliittiset näkemykset kamppailevat keskenään. Ammattikorkeakouluja ja nuorisoasteen koulutusta koskevia uudistuksia oli valmisteltu vuodesta 1989 ministeri Christoffer Taxellin johdolla. Hän siirtyi toisiin tehtäviin syksyllä 1990, ja ministerinä jatkoi Anna-Liisa Kasurinen. Hallitus antoi joulukuussa 1990 eduskunnalle esityksen laiksi nuorisoasteen koulutuksen ja ammattikorkeakoulujen kokeiluista. Laki ja asetus (L391/91 ja A 392/91) annettiin kaksi kuukautta myöhemmin ja ne tulivat voimaan maaliskuussa 1991. Puoluepoliittista keskustelua kokeilujen valmistelun aikana on selostettu tar-

KUVIO 1. Reformien analyysimalli Islingin (1980) mukaan.

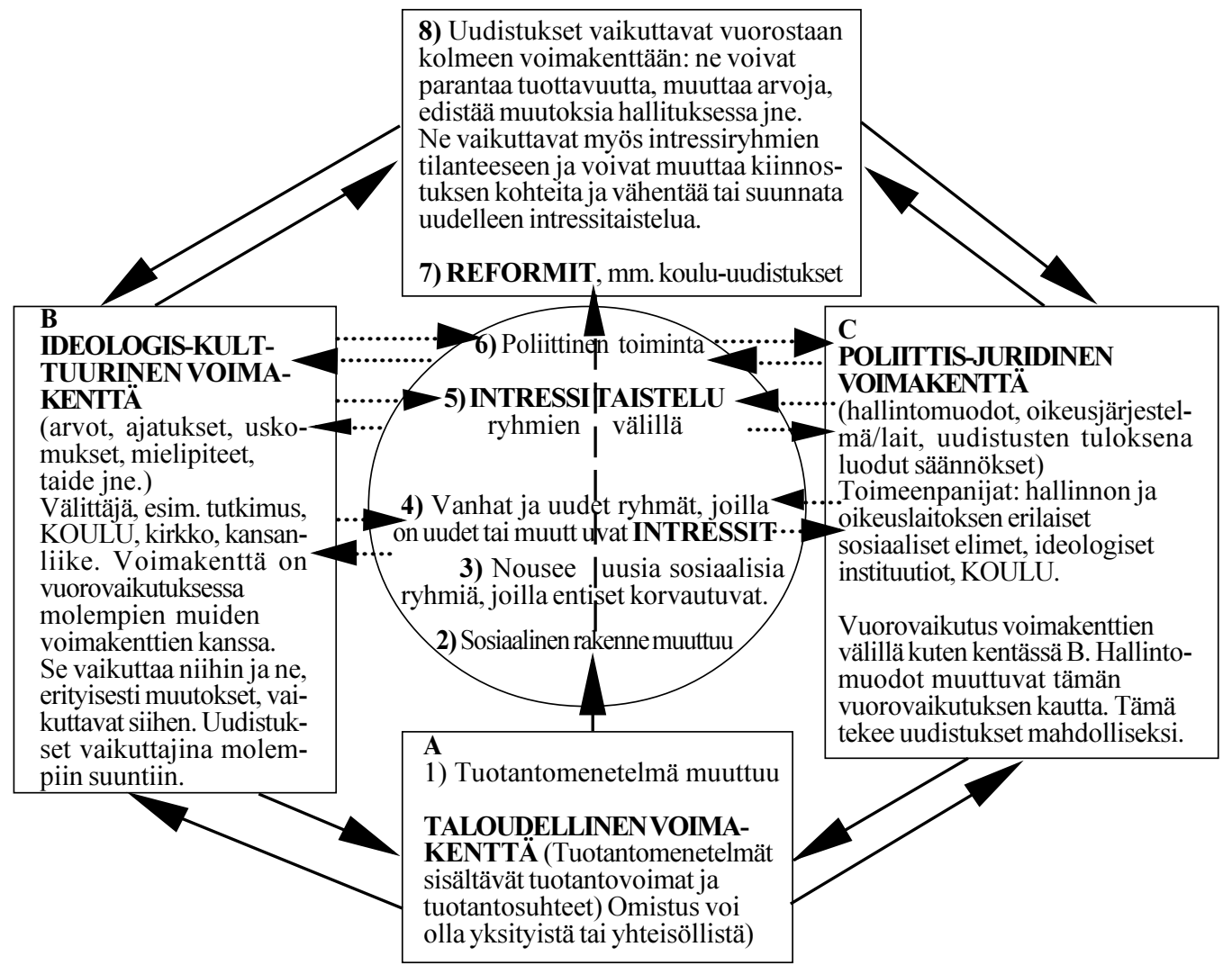

A-C indikoivat kolmea voimakenttää rakenteellisella tasolla.

1-8 indikoivat uudistusprosessia, toimintaa ryhmä- ja yksilötasolla intressien taistelussa.

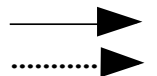

vaikutus rakenteellisella, yhteiskunnallisella tasolla

vaikutus ryhmä- ja yksilötasolla (yksilöt kuuluvat ryhmiin johtajina tai osallistujina) 
kemmin mm. Osmo Lampisen (1995) toimittamassa kirjassa Ammattikorkeakoulut -vaihtoehto yliopistoille. Suomalainen poliittis-juridinen voimakenttä muuttui hallituksen vaihtuessa keväällä 1991 ja keskusta-oikeistolaisen hallituksen tullessa valtaan Esko Ahon johtamana. Opetusministeriksi nimitettiin kokoomusta edustava Riitta Uosukainen. Ahon johtama hallitus ryhtyi määrätietoisesti kääntämään maan talouspolitiikan suuntaa. Tavoitteena oli hallitusohjelman mukaisesti siirtää talouden painopistettä suljetulta avoimelle sektorille, mikä edellytti julkisen talouden menojen voimakasta supistamista. Opetusministeriön hallinnonalan budjettikehystä vuosille 1992-1994 karsittiin 550 miljoonalla markalla. Poliittis-juridinen voimakenttä $\mathrm{C}$ siis liikkui, ja taloudellinen voimakenttä A heikkeni.

I slingin (emt) mukaan koulutusreformit ja muutokset tuotetaan oleellisesti juuri lopputuloksena olevissa uusissa ideologisissa ja poliittisissa intresseissä ja konflikteissa. Ammattikorkeakoulujen kehitystä tarkastellen ideologisista ja poliittisista intresseistä ja konflikteista on ehkä enemmänkin ollut hyötyä kuin haittaa niiden kehitykselle: kilpailu ja tahto osoittaa oma paikkansa koulutusjärjestelmässä tiedekorkeakoulusektorin rinnalla on vauhdittanut ammattikorkeakoulujen kehitystä ja saanut aikaan mittavia kehittämisponnistuksia (esimerkiksi tuhansien opettajien koulutustason nosto, opintojen kansainvälistyminen opettaja- ja opiskelijavaihtojen avulla, oppilaitosten työelämäyhteydet, kehitys- ja tutkimustyö, projektityöskentely, koulutuksen laadun ja arvioinnin korostuminen jne).

Islingin mallissa ryhmä- ja yksilötason toiminta (katkonuolet) vaikuttaa ideologis-kulttuuriseen ja poliittis-juridiseen voimakenttään ja näiden kenttien vaikutus puolestaan ilmenee yksilöiden ja ryhmien intressitaisteluissa ja poliittisessa toiminnassa. Mallia voi silti kritisoida tietystä mekanistisuudesta, nuolien keskinäinen ajoittuminen ei mallista avaudu.

Koulutuspoliittisia toimia ja -päätöksentekoa ohjaavat kulloinkin valitut arvot. Koulutuspoliittista päätöksentekoa koskevassa analyysissään Kogan (1975) kokosi 35 poliittista teemaa. Näitä voitiin analysoida 'koulutuksellisten ja kasvatuksellisten' (educational), 'sosiaalisten', taloudellisten' ja 'institutionaalisten' arvojen perusteella. Arvot näyttivät olevan yhteydessä kahteen muuhun luokitukseen: jatkuvuuteen ja politiikkaa edistävien intressiryhmien institutionaaliseen statukseen tai legitimiteetin asteeseen. Koulutukselliset/kasvatukselliset arvot olivat sellaisen politiikan pohjana, joka on suuressa määrin jatkuvaa. Institutionaalisten arvojen olemassaolo on voimakkaasti yhteydessä koulutuksellisten/kasvatuksellisten arvojen etenemiseen. Taloudelliset ja sosiaaliset arvot olivat epävakaisempia eivätkä jatkuvia. Myös tästä näkökulmasta suomalainen koulutusoptimismi ja taloudellisten resurssien kohtuullinen turvaaminen asettuvat mielenkiintoiseen valoon: taloudelliset arvot tavoitteina näyttävät olleen erilaisin painotuksin mukana koulutuspoliittisia uudistuksia koskevassa päätöksenteossa lähes koko kuluneen vuosisadan ajan.

\section{YHTEENVETOA}

Koulutuspolitiikalla on maassamme varsin vakiintunut asema, eikä sen merkitystä ole asetettu kyseenalaiseksi edes huolimatta viime vuosien huomattavista säästö- ja rationalisointipaineista koulutuksen kaikilla alueilla. Nurmi et.al (1996) toteavat, että vaikka poliittisilla puolueilla on erilaisia käsityksiä markkinatalouden suhteesta julkishallintoon, ne eivät ole olleet kovin erimielisiä koulutuksesta. Pekkarisen ja Vartiaisen (1993, 115) mukaan talouden suhdannevaihtelut ovat Suomessa olleet kansainvälisesti verraten voimakkaita, mutta mekanismeiltaan varsin säännöllisiä ja muuttumattomia.

Koulutusjärjestelmän kehitys on meillä liittynyt voimakkaasti rakennemuutokseen ja hyvinvointivaltion kehittymiseen (ks. Kivinen 1988; Järvelä 1991), millä perusteella Väärälän (1995) mukaan suomalaista koulutusjärjestelmää on tarkasteltava osana hyvinvointivaltion kokonaisjärjestelmää. Keskiasteen koulunuudistuksen ajalle, 1960-70 -lukujen vaihteelle, samoin kuin ammattikorkeakoulu-uudistuksen ja nuorisoasteen koulutuskokeilujen käynnistymisajankohdalle 
1990-luvun alussa oli tyypillistä usko taloudellisen kasvun ja kehityksen jokseenkin tasaiseen jatkuvuuteen. 1980-luku oli Euroopassa heikon talouskehityksen aikaa, mutta Suomen talouskasvu sen sijaan oli vakaata ja kansainvälisesti vertaillen nopeaa ( Pekkarinen \& Vartiainen, 126). Vaikkakaan häiriöttömän taloudellisen kehityksen takaama tulevaisuus ei ollut enää 1980-luvun lopussa aiemmanlainen itsestäänselvyys, varsinainen kriisi ja taloudellinen romahdus olivat vielä useimmille muille kuin taloustieteilijöille näkymättömissä. Ammattikorkeakoulu- ja nuorisoasteen koulutuskokeiluista päätettäessä 1991 eduskunta piti tärkeänä, että laskusuhdanteen aikana ei koulutusmenoista säästetä, vaan koulutusta juuri tällöin tuetaan, ja että julkisen vallan koulutusmenoihin käyttämää osuutta lisätään (Valtiopäivät 1992). Kun taloudellinen romahdus sitten koitti 1990-luvun alkuvuosina, olivat merkittävät koulutusreformit, ammattikorkeakoulukokeilu ja nuorisoasteen koulutuskokeilu jo käynnissä, eikä talouslama kaatanut niitä. Mistä syystä näin ei käynyt, vaikka koulutuksen menoja edellä mainitusta eduskunnan kannanotosta huolimatta opetusministeriön pääluokan keskeisissä tehtäväryhmissä leikattiin vuosina 1992-95 keskimäärin 14 prosenttia, on sinänsä pohdinnan arvoinen seikka (ks. alaviitteenä oleva taulukko sivulla 230). Talouskriisin runnellessa vihjailtiin 1990-luvun alussa toistuvasti Suomessa olevan liikaa korkeakouluja, ja taantuman kiristäessä ylimmän opetuksen julkista rahoitusta alettiin pohtia, onko koko maan kattava korkeakouluverkko tarpeellinen. Väläyteltiin myös puhtaasti eliittikorkeakoulujen mahdollisuutta. Samaan aikaan kuitenkin oli käynnissä korkeakoululaitoksen laajentaminen non-universitysektorille, kun ammatillista koulutusta nostettiin ammattikorkeakoulutasolle. Keskeisenä syynä voitaneen pitää juuri vankkaa uskoa erityisesti korkea-asteen koulutuksen merkitykseen kansantalouden kehitysveturina. Ammattikorkeakoulujen kehittämisessä on erityisen painokkaasti korostettu koulutuksen ja työelämän yhteyttä ja ammatillisen osaamisen merkitystä kansantaloudelle ja kansainväliselle kilpailukyvylle. Ammattikorkeakoulujen ohella myös tiedekorkeakoulut ovat lisänneet työelämäyhteyksiään.

Yliopistojen tuloksellisuuden merkitystä on kai- ken kaikkiaan korostettu 1980-luvun puolivälistä alkaen (Ketonen \& Nyyssölä 1996). Tuloksista palkitsemisessa voitaneen nähdä yhteyksiä puhtaasti kansantalouteen: yhteiskunnan panoksilla halutaan mahdollisimman hyvä tuotos, ja hyvillä tuotoksilla nähdään yhteys paitsi kulttuuriin ja henkisiin arvoihin, myös suoraan kansantalouteen. Ehkä tämänsuuntaisia ajatuksia on havaittavissa Aittolan \& Määtän $(1998,30)$ hämmästyksessä yritystutkijoitten vähäisestä osuudesta tutkijakoulujen ohjaajina jopa luonnontieteiden ja tekniikan tutkimusaloilla.

Useissa maissa korkea-asteen koulutuksen piiriin (tertiary level) kuuluu yhä suurempi osa ikäryhmästä. OECD-maissa tähän koulutukseen osallistuneiden määrä on muutamassa vuosikymmenessä nelinkertaistunut. Kehitysvauhti on vaihdellut maittain, mutta yleislinjana on ollut korkea-asteen koulutuksen volyymin lisääntyminen. Suomalaisen ammattikorkeakoulujärjestelmän luominen yliopistojen rinnalle noudattelee siten yleismaailmallista kehityskulkua, jossa olennaisena tekijänä on ollut maan taloudellisen kilpailukyvyn säilyttäminen korkea-asteen koulutusta lisäämällä ja kehittämällä.

\section{Lähteet}

AHOLA, S. (1995) Eliitin yliopistosta massojen koulutukseen. Korkeakoulutuksen muuttuva asema yhteiskunnallisen valikoinnin järjestelmänä. Koulutussosiologian tutkimuskeskus, raportti 30. Turun yliopisto. Painosalama Oy.

AITTOLA, H. \& Määttä, P. (1998) Tohtoriksi tutkijakoulusta. Tutkijakoulut tieteellisten jatko-opintojen uudistajina. Koulutuksen tutkimuslaitos. Tutkimuksia 3. Jyväskylän yliopisto. Jyväskylän yliopistopaino.

ANTIKAINEN, A. (1986) Koulutuksen tulevaisuus ja koulutuspolitiikka. Gaudeamus. Jyväskylä: Gummerus Oy.

A 392/1991. Asetus nuorisoasteen koulutuksen ja ammattikorkeakoulujen kokeiluista

Bray, M. \& Lillis, K. (ed) (1988) Community Financing of Education. Issues and Policy Implications in Less Developed Countries. Comparative and International Educational Series. Volume 5. Pergamon Press.

CASTELLS, M. (1994) The University System: Engine of Development in the New World Economy. Teoksessa J. Salmi \& A. M. Verspoor (ed.) Revitalizing Higher Education. Issues in Higher Education. Pergamon. IAU Press, $14-41$

COOMBS, H.P. \& Hallak, J. (1987) Cost Analysis in Education. A Tool for Policy and Planning. EDI 
Series in Economic Development. Published for The World Bank. The Johns Hopkins University Press. Baltimore and London.

ELOVAINIO, P. (1974) Korkeakoululaitoksen rakenne ja yhteiskunnan muutos. Eripainos, Sosiologia XI, 1974: 4. Helsingin yliopiston valtiotieteellinen tiedekunta. Väitöskirja.

ELOVAINIO, P. (1992) Muuttuva koulutus. Teoksessa O. Riihinen (toim.) Sosiaalipolitiikka 2017; Näkökulmia suomalaisen yritystoiminnan kehitykseen ja tulevaisuuteen. Juva: WSOY, 413 - 432.

GORDON, T. (1986) Democracy in one school ? Progressive Education and Restructuring. The Falmer Press, Education Policy Perspectives Series. Basingstoke: Taylor \& Francis Ltd.

HERNESNIEMI, H. \& Lammi, M.\& Ylä-Anttila, P. (1995) Kansallinen kilpailukyky ja teollinen tulevaisuus Elinkeinoelämän tutkimuslaitos ETLA, Suomen itsenäisyyden juhlarahasto SITRA. Sarja B105. SITRA 145. Helsinki: Taloustieto Oy.

HOVI, Kivinen \& Rinne. (1989) Komitealaitos, koulutusmietinnöt ja koulutuspolitiikan oikeutus. Turun yliopisto. Turku 1989.

HÄYRYNEN,Y.- P. (1992) Henkisten kykyjen tuottavuus ja 1990 -luku. Teoksessa L. Lehtisalo (toim.)Vaikuttaako koulutus. Opetusministeriö: VAPK-kustannus, $51-123$.

ISLING, Å. (1980) Kampen för och mot en demokratisk skola. 1. Samhällsstruktur och skolorganisation. A Dissertation for the Doctor's Degree in social sciences. University of Stockholm Stockholm: Sober Förlag AB

ISOAHO, H.\& Kivinen, O.\& Rinne, R. (1990) Education and the family background of the young in Finland. Tutkimuksia. Nro 172. Tilastokeskus. Helsinki.

JÄRVELÄ, M. (1991) Palkkatyö ja koulutustarve. Tutkimus palkkatyön kasvusta, ammatillistumisesta ja toimijoiden strategioista Suomessa toisen maailmansodan jälkeen. Tutkijaliitto. Helsinki: Priima-Offset Ky

KALELA, J. (1989) Eroavuuden ja jatkuvuuden ristiriita Pentti Renvallin historianäkemyksessä. Teoksessa M. Majander (toim.) Ajankohta. Poliittisen historian vuosikirja 1992. Helsingin yliopiston poliittisen historian laitoksen julkaisuja. Helsinki: Tutkijaliitto

KetONEN, K. \& Nyyssölä, K. (1996) Palkitsemisen politiikka. Tuloksellisuusperiaate suomalaisessa korkeakoulupolitiikassa. Koulutussosiologian tutkimuskeskus. Raportti 39. Turun yliopisto: Painosalama OY.

KIVINEN, O. (1988) Koulutuksen järjestelmäkehitys. Peruskoulutus ja valtiollinen kouludoktriini Suomessa 1800- ja 1900-luvuilla. Turun yliopiston julkaisuja. Sarja C, osa 67. Turku.

KIVINEN, O. \& Rinne, R. \& Ahola, S. (1989) Koulutuksen rajat ja rakenteet. Juva: WSOY

KOGAN, M. (1975) Educational Policy-Making. A Study of Interest Groups and Parliament. Ruskin House. London: George Allen \& Unwin Ltd.

KOGAN, M. (1979) Education Policies in Perpesctive: an appraisal. Reviews of National Policies for Education. Paris: OECD.

Koulutuksen tavoiteohjelmatoimikunnan mietintö.(1978) Komiteanmietintö 1978:61. Helsinki
KUUSI, P. (1962) 60-luvun sosiaalipolitiikka. Porvoo.

L 391/1991 Laki nuorisoasteen koulutuksen ja ammattikorkeakoulujen kokeiluista.

LAMPINEN, O. (toim.) (1995) Ammattikorkeakoulut vaihtoehto yliopistolle. Gaudeamus, Otatieto Oy. Tampere:Tammer-Paino.

LAMPINEN, O. (1998) Suomen koulutusjärjestelmän kehitys. Gaudeamus. Tampere: Tammer-Paino Oy.

LAMPINEN, O. \& Savola, M. (1995) Ammattikorkeakoulujen syntyvaiheet Suomessa. Teoksessa O. Lampinen (toim.) Ammattikorkeakoulut - vaihtoehto yliopistolle. Gaudeamus, Otatieto Oy. Tampere:Tammer-Paino, 26 - 80

LAMPINEN, O. \& Soininvaara, O. (1980) Suomi 1980luvulla. Juva: WSOY.

LAPPALAINEN, A. (1991) Suomi kouluttajana. Porvoo: WSOY.

LEHTISALO, L. \& Raivola, R. (1992) Koulutuspolitiikka. Juva: WSOY

LINDSAY, B. (1990) Educational Equity in Cross-National Settings, How do nations build educational bridges and dismantle educational barries? Teoksessa R. M. Thomas (ed.) International Comparative Education; Practices, Issues \& Prospects. Oxford: Pergamon Press, 199-203.

LOIKKANEN, H. A. \& Pekkarinen, J . \& Siimes, S-A. \& Vartia, P. (toim.)(1997) Kansantaloutemme - rakenteet ja muutos. Taloustieto Oy. Tampere: Tammer-Paino Oy.

MARKLUND, S. (1984) Sweden. Teoksessa J. R. Hough (ed.) Educational Policy. An International Survey. Croom Helm.London \& Sydney. New York: St. Martin's Press, $136-182$

MEKLIN, P. (1997) Valtiontalouden perusteet. 3., uudistetu painos. Hallinnon kehittämiskeskus. Helsinki: Edita

MURRAY, M. (1988) Utbildningsexpansion, jämlikhet och avlänking. Studier $i$ utbildningspolitik och utbildningsplanering 1933-1985. Göteborg studies in educational sciences 66. Acta universitatis Gothoburgensis. Göteborg: Vasastadens Bokbinderi $\mathrm{AB}$.

NUKARI, J. \& Forsell, M. (1999) Suomen ohjelmistoteollisuuden kasvun strategia ja haasteet. Teknologiakatsaus 67/ 99. Teknologian kehittämiskeskus TEKES. Sipoo: Paino-Center Oy.

NUMMINEN, J. (1977) Keskiasteen koulutuksen uudistaminen. Keuruu: Otava

NURMI, K. \& Kontiainen, S. \& Tissari, V. (1996) Asiantuntijoiden käsitys Suomen aikuiskoulutuksesta. Suomen Eurodelfoitutkimus 1996. Aikuiskoulutuksen tulevaisuus Euroopassa. Helsinki: Hakapaino $\mathrm{Oy}$.

Opetushallitus (1994) Koulutuksen kuva. Tilastoja koulutuksesta ja koulutettavista. Helsinki.

Opetusministeriö. (1989) Peruskoulun jälkeisen koulutuksen kehittäminen. Opetusministeriön pyytämät selvitykset nuorisoasteen koulutuksen ja ammattikorkeakoulun kehittämisvaihtoehdoista, niiden organisointitavoista ja kokeilumahdollisuuksista. Opetusministeriön työryhmien muistioita 1989:54. Helsinki. Opetusministeriö/monistamo.

PAPADOPOULOS, G. S. (1994) Education 1960 - 1990. The OECD Perspective. OECD Historical Series. Paris. 
PEKKARINEN, J. \& Vartiainen, J. (1993) Suomen talouspolitiikan pitkä linja. Juva. WSOY.

PESTON, M. (1981) Higher Education Policy. Teoksessa R. Lindley (ed.) Higher Education and the Labour Market. Programme of Study into the Future of Higher Education. Society for Research into Higher Education. Research into Higher Education Monographs. Direct Printers. Butts Pond, $120-147$.

RAIVOLA, R. (1992) Koulutuksen vaikuttavuuden problematiikasta. Teoksessa L.Lehtisalo (toim.) Vaikuttaako koulutus. Opetusministeriö: VAPK-kustannus, $125-179$.

SALMINEN, H. (1997) Miksi ja miten suomalainen ammattikorkeakoulu perustettiin. Tarkastelu suunnitteluprosessin käynnistymisestä ensimmäisten ammattikorkeakoulujen vakinaistamiseen 1.8.1996. Kasvatustieteen lisensiaattityö. Jyväskylän yliopisto

SALMINEN, H. (1998) Suomalaisen ammattikorkeakoululaitoksen tausta ja suunnitteluprosessi. Hallinnon tutkimus 1/1998. Vammala: Vammalan kirjapaino Oy, 36-42.

SARJALA, J. (1981) Suomalainen koulutuspolitiikka Juva: WSOY.

SUORANTA, J. \& Ylä-Kotola, M. (1999) Tiedonjärjestykset ja uusi yliopisto. Kasvatus 3/1999.

Katsaus. Jyväskylä: Kirjapaino Oma, 306-312.

TUNNERMANN, C. (1996) A new vision of higher education. Higher Education Policy. The Quarterly Journal of the International Association of Universities (IAU). Vol 9, No 1, March 1996. Pergamon. Great Britain: Elsevier Science Ltd., 11 - 27.

Valtioneuvoston koulutuspoliittinen selonteko Eduskunnalle (1990). Suomen koulutusjärjestelmä, koulutuksen taso ja kehittämislinjat. Helsinki: Valtion painatuskeskus.

Valtiopäivät (1992). Eduskunnan kannaotot valtioneuvoston Suomen koulutusjärjestelmää, koulutuksen tasoa ja kehittämisen linjoja koskevaan selontekoon. Hallituksen kertomus vuoden 1991 toiminnasta, asiakirja B1, 170-172.
VÄÄRÄLÄ, R. (1995) Ammattikoulutus ja kvalifikaatiot. Acta Universitatis Lapponiensis. Lapin yliopisto. Rovaniemi.

\section{Viitteet}

1 Opetusministeriö toteuttaa tietoteollisuuden tarvitseman koulutuksen ja tutkimuksen laajentamista koskevan toimenpideohjelman vuosina 1998-2002. Ohjelma koskee sähkö-ja tietotekniikka-, elektroniikka-, tietoliikenneja tietojenkäsittelyaloja eri koulutustasoilla ja oppilaitosmuodoissa.

Kertaluonteisina toimenpiteinä otetaan muunto-ja siirtokoulutukseen yliopistoissa vuosina 1998-2002 yhteensä 5150 ja ammattikorkeakouluissa 3400 uutta opiskelijaa. Ammatillisessa aikuiskoulutuksessa on datanomin tutkintoon johtavaa koulutusta lisätty noin 400 uudella opiskelijalla/vuosi vuosina 19981999. Ammattikorkeakoulujen näiden alojen erikoistumisopintoihin otetaan 2400 uutta opiskelijaa ohjelmavuosina.

Tietoteollisuudenalojen pysyvää koulutustarjontaa lisätään yliopistoissa vuodesta 1999 lähtien asteittain siten, että vuodesta 2000 lähtien uusien opiskelijoiden määrä on 1000 suurempi kuin aiemmin suunniteltu vuoden 1998 taso. Ammattikorkeakoulujen pysyvää tarjontaa lisätään vuodesta 1999 lähtein asteittain siten, että vuodesta 2000 lähtien uusien opiskelijoiden määrä on 1400 suurempi kuin aiemmin suunniteltu vuoden 1998 taso. Tutkijakoulutusta tietoteollisuuden tarvitsemilla aloilla lisätään 60:1la tutkijakoulutuspaikalla vuonna 1999. Edellä mainittujen toimenpiteiden lisäksi lisätään aikuiskoulutustarjontaa, työvoimakoulutusta, tutkintojen osiin johtavaa työvoimapoliittista ja omaehtoista koulutusta sekä oppisopimuskoulutusta em. aloilla.

2 Opetusministeriön pääluokan keskeisten tehtäväryhmien menojen kehitys (mmk, hintataso 1994). (Alapuolella oleva taulukko).

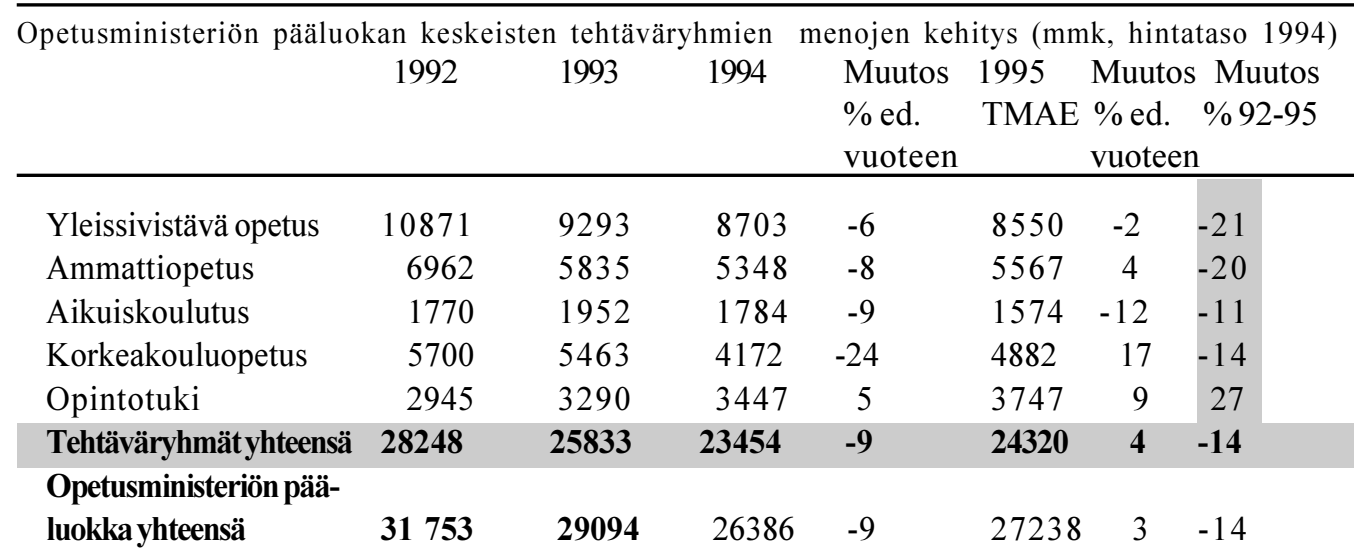

Taulukossa 1. on esitetty opetusministeriön pääluokan keskeisten tehtäväryhmien menojen kehitys vuosina 1992-1995. Ainoana pääluokan ryhmänä opintotukeen tuli lisäystä; kaikilla muilla koulutuksen alueilla menoja leikattiin huomattavassa määrin, kaikissa tehtäväryhmissä ja opetusminsiteriön pääluokassa menojen vähennys oli neljän vuoden aikana yhteensä 14 prosenttia. Lähde: Opetushallitus 1994. Koulutuksen kuva.Tilastoja koulutuksesta ja koulutettavista.

Artikkeli saapui toimitukseen 15.10.1998. Se hyväksyttiin julkaistavaksi 20.8.1999. 